\title{
PENGARUH KEMAMPUAN DIRI, KOMITMEN ORGANISASI DAN BUDAYA ORGANISASI TERHADAP KINERJA PEGAWAI DI DINAS KEPENDUDUKAN DAN PENCATATAN SIPILKABUPATEN ACEH BARAT
}

\author{
${ }^{1}$ Sayid Priyakesuma, ${ }^{2}$ Naswan Efendi, ${ }^{3}$ Syarmadan Simamora, ${ }^{4}$ Riswan Halim Batubara, ${ }^{5}$ Rahmad Perdana \\ Harianja \\ $1,2,3,4,5$ Universitas Islam Sumatera Utara \\ ${ }^{1}$ sayid.priyakesuma@gmail.com ${ }^{2}$ naswan.efendi@gmail.com,33yarmadan.simamora@gmail.com, \\ ${ }^{4}$ riswan.halim@gmail.com, ${ }^{5}$ rahmad.perdana@gmail.com,
}

\begin{abstract}
The problems in research what is influence of self ability on performance. What is influence of organizational commitment on performance. What is influence of organization culture on performance. What is influence of self ability, organizational commitment and organization culture on performance. The research of purposes is for know and analysis influence of self ability on performance. For know and analysis influence of organizational commitment on performance. For know and analysis influence of organization culture on performance. For know and analysis influence of self ability, organizational commitment and organization culture on performance. Samples in the research amount to 32 employees people. Data analyze technique in the research using descriptive analyze and regression analize. The results of this research explain of self ability variable effect significant and positive on performance. Organizational commitment variable effect significant and positive on performance. Organization culture variable effect significant and positive on performance. Self ability, organization commitment and organization culture variable effect significant and positive on performance.
\end{abstract}

Keywords : Self ability, Organizational commitment, Organization culture, Performance

ABSTRAK : Rumusan masalah dalam penelitian ini adalah apakah ada pengaruh kemampuan diri terhadap kinerja. Apakah ada pengaruh komitmen organisasi terhadap kinerja. Apakah ada pengaruh budaya organisasi terhadap kinerja. Apakah ada pengaruh kemampuan diri, komitmen organisasi dan budaya organisasi terhadap kinerja. Tujuan penelitian ini adalah untuk mengetahui dan menganalisis pengaruh kemampuan diri terhadap kinerja. Untuk mengetahui dan menganalisis pengaruh komitmen organisasi terhadap kinerja. Untuk mengetahui dan menganalisis pengaruh budaya organisasi terhadap kinerja. Untuk mengetahui dan menganalisis pengaruh kemampuan diri, komitmen organisasi dan budaya organisasi terhadap kinerja. Sampel dalam penelitian ini berjumlah 32 orang pegawai. Teknik analisis data dalam penelitian ini menggunakan analisis deskriptif dan analisis regresi linier berganda. Hasil penelitian ini menjelaskan bahwa variabel kemampuan diri berpengaruh positif dan signifikan terhadap kinerja. Variabel komitmen organisasi berpengaruh positif dan signifikan terhadap kinerja,. Variabel budaya organisasi berpengaruh positif dan signifikan terhadap kinerja. Variabel kemampuan diri, komitmen organisasi dan budaya organisasi berpengaruh positif dan signifikan terhadap kinerja

Kata kunci : Kemampuan diri, Budaya organisasi, Komitmen organisasi, Kinerja

\section{Pendahuluan}

Dinas Kependudukan Dan Pencatatan Sipil Kabupaten Aceh Barat dalam melaksanakan setiap program yang tertuang dalam program kerja diharapkan dapat menerapkan prinsipprinsip transparansi, efisien dan akuntabilitas. Prinsip ini diperlukan sebagai semangat guna mendukung program pelaksanaan pengelolaan pemerintah yang baik (good governance). Dinas Kependudukan Dan Pencatatan Sipil Kabupaten Aceh Barat dalam melaksanakan tugas sesuai dengan struktur organisasi yang memungkinkan sumber daya manusia yang berkualitas dan kompetitif sehingga mampu beradaptasi dengan kemajuan ilmu dan dan perkembangan teknologi guna 
menghasilkan kinerja dan pelayanan terbaik sesuai dengan yang diharapkan.

Untuk melihat kinerja seseoarng, maka perlu dilakukan penilaian kinerja secara objektif dan sesuai dengan peraturan yang berlaku. Nilai penting dari penilaian kinerja adalah menyangkut penentuan tingkat kontribusi individu atau kinerja yang diekspresikan dalam penyelesaian tugas-tugas yang menjadi tanggungjawabnya. Penilaian kinerja pada dasarnya merupakan salah satu faktor kunci guna mengembangkan suatu organisasi secara efektif dan efisien, karena adanya kebijakan atau program penilaian prestasi kerja, berarti organisasi telah memanfaatkan secara baik atas SDM yang ada dalam organisasi. Permasalahan yang biasa muncul dalam proses penilaian adalah terletak pada bagaimana objektivitas penilaian dapat dipertahankan. Dengan kemampuan mempertahankan objektivitas penilaian, maka hasil penilaian menjadi terjaga akurasi dan validitasnya. Untuk menjaga sistem penilaian yang objektif hendaknya para penilai, harus menghindarkan diri dari adanya faktor suka atau tidak suka. Keberhasilan suatu organisasi dalam rangka mencapai tujuan tergantung dari kemampuan dan keandalan sumberdaya manusia yang mengoperasikan unit-unit kerja yang terdapat di dalam organisasi bersangkutan. Untuk itu diperlukan kinerja yang tinggi dari pelaku-pelaku kegiatan tersebut.

Dalam upaya untuk memaksimalkan kemampuan yang dimiliki para pegawai maka Dinas Kependudukan Dan Pencatatan Sipil Kabupaten Aceh Barat melakukan berbagai bentuk atau kegiatan yang dilakukan untuk meningkatkan kemampuan diri para pegawai. Upaya nyata tersebut yaitu dengan adanya program pengembangan kompetensi yang terdiri dari pengembangan bakat dan kepemimpinan dan program edukasi. Upaya lain yang dilakukan dinas untuk mengembangkan kompetensi atau kemampuan para pegawai yaitu dengan memberikan fasilitas knowledge management, dimana setiap pegawai berkesempatan untuk bertukar ide, konsep dan berbagi informasi melalui artikel yang dapat diakses oleh semua pegawai Dinas Kependudukan Dan Pencatatan Sipil Kabupaten Aceh Barat dalam upaya untuk mengembangkan kemampuan kerja para pegawai juga mengikutsertakan para pegawai untuk mengikuti pelatihan yang diselenggarakan oleh Provinsi maupun pusat.
Kebijakan-kebijakan terkait dengan pengembangan potensi atau kemampuan kerja para pegawai tersebut menjadikan peranan pengembangan kemampuan diri pegawai menjadi hal penting untuk dilakukan.

Faktor lainnya yang dapat mempengaruhi kinerja pegawai Dinas Kependudukan Dan Pencatatan Sipil Kabupaten Aceh Barat adalah komitmen organisasi. Sekarang ini komitmen organisasi dapat dijadikan landasan daya saing, karena organisasi atau instansi dengan pegawai yang mempunyai komitmen akan mendapatkan keunggulan-keunggulan yang tidak dimiliki oleh organisasi atau instansi lain seperti adanya kepercayaan yang kuat untuk menerima tujuan dan nilai-nilai organisasi, kesediaan untuk melakukan usaha yang diatasnamakan organisasi, serta adanya keinginan yang kuat untuk mempertahankan keanggotaannya di dalam organisasi tersebut. Oleh karena itu, komitmen organisasi menjadi isu penting dalam konstelasi perubahan organisasi yang di dalamnya terkait dengan manajemen dan perilaku sumber daya manusia atau pegawai. Pada komitmen organisasi terkait dengan rasa identifikasi (kepercayaan terhadap nilai-nilai organisasi), keterlibatan (kesediaan untuk berusaha sebaik mungkin demi kepentingan organisasi) dan kompetensi (keinginan untuk tetap menjadi anggota organisasi yang bersangkutan). Tiga unsur utama dalam komitmen organisasi (rasa identifikasi, keterlibatan dan kompetensi) tersebut menjadi dasar yang sangat penting bagi pegawai untuk mencapai keberhasilan dalam melaksanakan tugasnya, sehingga tercipta kinerja yang baik. Dengan demikian pegawai yang mempunyai komitmen yang tinggi terhadap organisasi, maka akan meningkatkan kinerja pegawai tersebut. Penelitian terdahulu yang menyatakan komitmen organisasi mempunyai pengaruh yang signifikan terhadap kinerja diantaranya hasil penelitian dari Windy dan Gusnati (2012); Murgianto, Sulasmi, S., dan Suhermin. (2016); Setyaningdyah (2013); Soepardjo, Tanisa Arsya dan Nugrohoseno, Dwiarko (2014).

Faktor lain yang dapat meningkatkan kinerja pegawai Dinas Kependudukan Dan Pencatatan Sipil Kabupaten Aceh Barat yaitu budaya organisasi. Budaya organisasi yang kuat akan mempunyai sifat kompetitif. Budaya organisasi yang kuat akan menuntun perilaku dan memberi makna pada setipa kegiatan organisasi. Sebaliknya jika budaya organisasi yang ada bertentangan dengan tujuan, 
kebutuhan dan motivasi pribadi, kemungkinan yang timbul adalah kinerja pegawai menjadi menurun. Dengan kata lain suatu organisasi ditentukan oleh interaksi antara kebutuhan dengan budaya organisasi yang ada dalam organisasi tersebut. Penelitian terdahulu dari Jatilaksono, Raditya (2016); Maskur, (2010); Muchtar Adama (2014); Pranoto, Paulus Sugiyo. (2014); Soepardjo, Tanisa Arsya dan Nugrohoseno, Dwiarko (2014), kesemuanya menarik kesimpulan budaya organisasi berpengaruh signifikan terhadap kinerja, walaupun penelitian yang dilakukan pada objek yang berbeda-beda.

Fenomena yang terjadi pada Dinas Kependudukan Dan Pencatatan Sipil Kabupaten Aceh Barat bahwa dalam mendukung kinerja, pegawai belum dapat menunjukkan kondisi yang optimal, masih kurangnya kemauan pegawai untuk berkompetisi dalam pelaksanaan tugas dan masih belum optimalnya koordinasi dalam mendukung mekanisme teamwork dalam bekerja. Faktanya antara lain masih adanya keluhan para pegawai dalam menjalankan pekerjaannya masih terjadi dan penguasaan informasi teknologi masih perlu peningkatan. Gejala seperti ini jelas akan mengganggu kinerja pegawai sehingga perlu dilakukan pembenahan untuk meningkatkan kinerja Dinas Kependudukan Dan Pencatatan Sipil Kabupaten Aceh Barat. Selain dari pada itu tingkat kehadiran pegawai juga belum sepenuhnya menunjukkan kinerja yang baik karena masih ada pegawai yang datang terlambat, pulang sebelum jam kantor serta tidak berada di meja kerja pada waktu jam kerja.

\subsection{Batasan Masalah}

Berdasarkan uraian di atas, banyak faktor yang berpengaruh pada variabel kinerja pegawai Dinas Kependudukan Dan Pencatatan Sipil Kabupaten Aceh Barat, sehingga dalam penelitian ini peneliti membatasi kepada variabel independen yaitu kemampuan diri, komitmen organisasi, budaya organisasi dan kinerja pegawai.

\subsection{Hioptesis}

Berdasarkan uraian teoritis dan kerangka konseptual di atas, maka dapat ditarik hipotesis penelitian ini sebagai berikut :

1) Kemampuan diri berpengaruh positif dan signifikan terhadap kinerja pegawai di Dinas Kependudukan Dan Pencatatan Sipil Kabupaten Aceh Barat.
2) Komitmen organisasi berpengaruh positif dan signifikan terhadap kinerja pegawai di Dinas Kependudukan Dan Pencatatan Sipil Kabupaten Aceh Barat.

3) Budaya organisasi berpengaruh positif dan signifikan terhadap kinerja pegawai di Dinas Kependudukan Dan Pencatatan Sipil Kabupaten Aceh Barat.

4) Kemampuan diri, komitmen organisasi dan budaya organisasi berpengaruh positif dan signifikan terhadap kinerja pegawai di Dinas Kependudukan Dan Pencatatan Sipil Kabupaten Aceh Barat.

\subsection{Tujuan Penelitian}

Tujuan dari penelitian ini adalah :

1) Untuk mengetahui dan menganalisis pengaruh kemampuan diri terhadap kinerja pegawai di Dinas Kependudukan Dan Pencatatan Sipil Kabupaten Aceh Barat.

2) Untuk mengetahui dan menganalisis pengaruh komitmen organisasi terhadap kinerja pegawai di Dinas Kependudukan Dan Pencatatan Sipil Kabupaten Aceh Barat.

3) Untuk mengetahui dan menganalisis pengaruh budaya organisasi terhadap kinerja pegawai di Dinas Kependudukan Dan Pencatatan Sipil Kabupaten Aceh Barat.

4) Untuk mengetahui dan menganalisis pengaruh kemampuan diri, komitmen organisasi dan budaya organisasi terhadap kinerja pegawai di Dinas Kependudukan Dan Pencatatan Sipil Kabupaten Aceh Barat.

\section{Metode Penelitian}

\subsection{Populasi}

Menurut Sugiyono (2010:90) populasi adalah wilayah generasi yang terdiri dari atas objek/subjek yang mempunyai kualitas karakteristik tertentu yang disajikan oleh peneliti untuk dipelajari dan kemudian ditarik kesimpulannya. Berdasarkan defenisi tersebut, maka populasi dalam penelitian ini adalah para pegawai Dinas Kependudukan Dan Pencatatan Sipil Kabupaten Aceh Barat yang berjumlah 32 orang.

\subsection{Sampel}

Menurut Sugiyono (2010:93), sampel adalah elemen-elemen populasi yang dipilih atas dasar kemampuan mewakilinya. Untuk menjadi pedoman jika subjeknya atau populasinya kurang dari 100, maka lebih baik diambil semua sebagai sampel, sehingga penelitiannya merupakan penelitian populasi. Selanjutnya jika 
jumlah subjeknya atau populasinya besar atau lebih dari 100, maka dapat diambil persentasenya. Dengan teknik penarikan sampel secara total sampling, maka sampel dalam penelitian ini seluruh populasi yaitu 32 orang pegawai Dinas Kependudukan Dan Pencatatan Sipil Kabupaten Aceh Barat.

Tabel 1. Distribusi sampel berdasarkan bagian

\begin{tabular}{|c|l|c|}
\hline No & \multicolumn{1}{|c|}{ Keterangan } & Jumlah (Orang) \\
\hline 1 & Sekretariat & 7 \\
\hline 2 & Bidang Pelayanan Pendaftaran Pendudk & 9 \\
\hline 3 & Bidang Pelayanan Pencatatan Sipil & 8 \\
\hline 4 & Bidang PIAK dan Pemanfaatan data & 32 \\
\hline \multicolumn{2}{|c|}{ Total } \\
\hline
\end{tabular}

Sumber : Dinas Kependudukan dan Pencatatan Sipil Kab. Aceh Barat, 2020

\subsection{Uji Normalitas}

Menurut Sugiyono (2014:144) pengertian dari uji normalitas adalah untuk menguji apakah nilai residual yang dihasilkan dari regresi terdistribusi secara normal atau tidak. Model regresi yang baik adalah yang memiliki nilai residual yang terdistribusi normal. Untuk mengetahui bentuk distribusi data, bisa dilakukan dengan grafik distribusi dan analisis statistik. Pengujian dengan distribusi dilakukan dengan melihat grafik histogram yang membandingkan antara dua observasi dengan distribusi yang mendekati distribusi normal. Distribusi normal akan membentuk satu garis lurus diagonal dan ploating data residual akan dibandingkan dengan garis diagonal. Jika distribusi atau residual normal, maka garis yang menggambarkan data yang sesungguhnya akan mengikuti garis diagonalnya. Uji normalitas dengan grafik dapat dilakukan dengan program SPSS dengan analisis grafik Normal Probability Plot

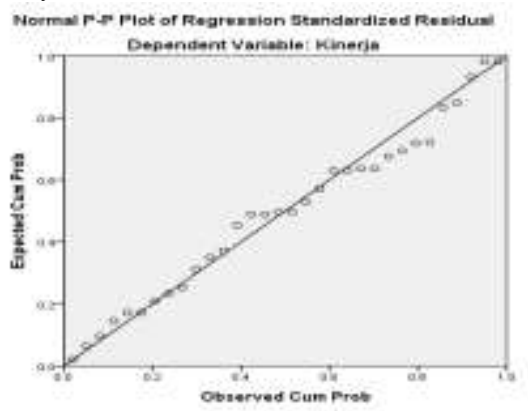

Gambar 1. Uji normalitas data

Berdasarkan gambar 1, diatas terlihat titiktitik dari ploating data residual berada di garis diagonal, hal ini dapat disimpulkan data yang diuji berdistribusi normal.

\subsection{Uji Multikolinieritas}

Salah satu asumsi dari model regresi linier bahwa tidak terjadi korelasi yang signifikan antara variabel bebasnya. Untuk menguji hal tersebut maka diperlukan suatu uji yang disebut uji multikolinieritas. Menurut Sugiyono (2014:151) pengertian multikolinieritas adalah keadaan di mana pada model regresi ditemukan adanya korelasi yang sempurna atau mendekati sempurna antar variabel independen. Pada regresi yang baik seharusnya tidak terjadi korelasi yang sempurna atau mendekati sempurna diantara variabel bebas. Uji multikolinieritas adalah untuk melihat ada atau tidaknya korelasi yang tinggi antara variabelvariabel bebasnya, maka hubungan antara variabel bebas terhadap variabel terikatnya menjadi terganggu. Jika terdapat korelasi yang kuat dimana sesama variabel independen maka konsekuensinya adalah :

a. Koefisien-koefisien regresi menjadi tidak dapat ditaksir

b. Nilai standar error setiap koefisien regresi menjadi tidak terhingga.

Dengan demikian, semakin besar korelasi diantara sesama variabel independen maka tingkat kesalahan dari koefisien regresi semakin besar yang dapat mengakibatkan standar error semakin besar pula. Cara yang digunakan untuk mendeteksi ada tidaknya multikolinieritas adalah dengan melihat besarnya nilai Variance Inflation Factor (VIF). Jika VIF dibawah 10 dan Tolerance Value diatas 0,1 maka tidak terjadi multikolinieritas.

Tabel 2. Uji multikolinieritas

\begin{tabular}{|l|c|c|}
\hline \multirow{2}{*}{ Variabel } & \multicolumn{2}{|c|}{ Collinearity Statistics } \\
\cline { 2 - 3 } & Tolerance & VIF \\
\hline Kemampuan diri & 0.887 & 1.127 \\
\hline $\begin{array}{l}\text { Komitmen } \\
\text { organisasi }\end{array}$ & 0.891 & 1.123 \\
\hline Budaya organisasi & 0.944 & 1.060 \\
\hline
\end{tabular}

Berdasarkan Tabel 2 diatas diperoleh nilai Tolerance Value diatas 0.1 yaitu 0.887, 0.891, 
0.944; hal ini menunjukan adanya korelasi yang cukup tinggi/kuat antara sesama variabel bebas dan nilai Variance Inflantion Factorrs (VIF) sebesar 1.127, 1.123, 1.060, dimana nilai VIF dari ketiga varibel bebas lebih kecil dari 10 dan dapat disimpulkan tidak terdapat multikolinieritas diantara ketiga variabel bebas yang diuji dalam penelitian ini.

\subsection{Uji Autokorelasi}

Uji autokorelasi merupakan pengujian dimana variabel dependen tidak berkorelasi dengan nilai variabel itu sendiri, baik nilai periode sebelumnya maupun nilai periode sesudahnya. Menurut Sugiyono (2014:172) pengertian dari autokorelasi adalah keadaan di mana pada model regresi ada korelasi antara residual pada periode tertentu $t$ dengan residual pada periode sebelumnya ( $\mathrm{t}-1$ ), model regresi yang baik adalah yang tidak terdapat masalah autokorelasi. Metode pengujian menggunakan uji Durbin-Watson (DW-test). Salah satu ukuran dalam menentukan ada tidaknya masalah autokorelasi dengan uji Durbin-Watson (DW) dengan ketentuan sebagai berikut :

$1.65<\mathrm{DW}<2.35$ tidak terjadi autokorelasi

1.21. $<\mathrm{DW}<1.65$ atau $2.35<\mathrm{DW}<2.79$ tidak dapat disimpulkan.

DW $<1.21$ atau DW $>2.79$ terjadi autokorelasi.

Tabel 3. Uji Autokorelasi

\begin{tabular}{|c|c|c|c|c|c|c|}
\hline \multirow[b]{2}{*}{ Model } & \multicolumn{5}{|c|}{ Change Statistics } & \multirow{2}{*}{$\begin{array}{l}\text { Durbin- } \\
\text { Watson }\end{array}$} \\
\hline & $\begin{array}{l}\text { R Square } \\
\text { Change }\end{array}$ & F Change & df1 & df2 & $\begin{array}{c}\text { Sig. F } \\
\text { Change }\end{array}$ & \\
\hline 1 & .496 & 9.182 & 3 & 28 & .000 & 2.015 \\
\hline
\end{tabular}

Berdasarkan Tabel 3di atas diperoleh nilai Durbin-Watson (DW) sebesar 2.015, nilai ini berada pada kisaran $1.65<\mathrm{DW}<2.35$, maka dapat disimpulkan bahwa tidak terjadi autokorelasi pada model regresi yang diuji dalam penelitian ini.

\subsection{Uji Heteroskedastisitas}

Uji heteroskedastisitas dapat dilakukan dengan menggunakan grafik scatterplot antara nilai variabel terikat (ZSPRED) dengan residualnya (SRESID), dimana sumbu $X$ adalah yang diprediksi dan sumbu $\mathrm{Y}$ adalah residual. Dasar pengambilan keputusan yang dapat diambil adalah sebagai berikut :

a. Jika pola tertentu seperti titik-titik yang ada membentuk suatu pola yang teratur (bergelombang, melebar kemudian menyempit) maka telah terjadi heteroskedastisitas.

b. Jika tidak ada yang jelas serta titik-titik menyebar diatas dan dibawah angka nol pada sumbu Y maka tidak terjadi heteroskedastisitas

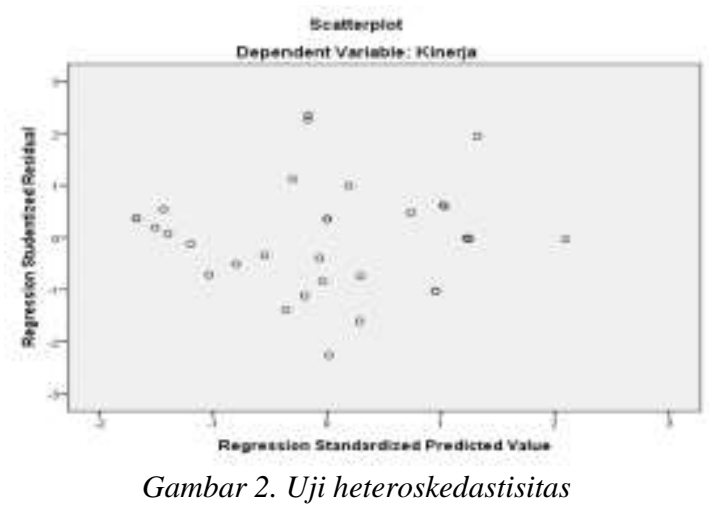

Berdasarkan gambar 2, diatas, menunjukkan titik-titik yang menyebar, sehingga dapat disimpulkan tidak terjadi heteroskedastisitas di data penelitian ini.

\section{Evaluasi Data}

\subsection{Analisis Regresi Linier Berganda.}

Analisis regresi linier berganda dalam penelitian ini dapat dilihat dari persamaan regresinya, dan dari hasil pengolahan data diperoleh hasil berikut ini :

Tabel 4. Analisis regresi linier berganda

\begin{tabular}{|c|c|c|c|c|c|}
\hline \multirow[b]{2}{*}{ Model } & \multicolumn{2}{|c|}{ Unstandardized Coefficients } & \multirow{2}{*}{$\begin{array}{c}\text { Standardized } \\
\text { Coefficients Beta }\end{array}$} & \multirow[b]{2}{*}{$\mathrm{t}$} & \multirow[b]{2}{*}{ Sig. } \\
\hline & $\mathrm{B}$ & Std. Error & & & \\
\hline (Constant) & .989 & 8.085 & & .122 & .904 \\
\hline Kemampuan diri & .269 & .129 & .298 & 2.092 & .046 \\
\hline Komitmen organisasi & .383 & .145 & .374 & 2.632 & .014 \\
\hline Budaya organisasi & .337 & .139 & .336 & 2.433 & .022 \\
\hline
\end{tabular}

Sumber : Hasil pengolahan data, 2020 
Berdasarkan Tabel 4, diatas dapat dibuat persamaan regresi dalam penelitian ini sebagai berikut :

$\mathrm{Y}=0.989+0.269 \mathrm{X}_{1}+0.383 \mathrm{X}_{2}+0.337 \mathrm{X}_{3}+\mathrm{e}$ Dari persamaan regresi linier berganda di atas dapat dijelaskan :

1) Nilai kinerja pegawai di Dinas Kependudukan Dan Pencatatan Sipil Kabupaten Aceh Barat sebesar 0.989, dengan ketentuan nilai dari variabel bebas $\left(\mathrm{X}_{1}, \mathrm{X}_{2}\right.$, dan $\left.\mathrm{X}_{3}\right)$ diabaikan.

2) Nilai koefisien regresi $X_{1}$ (kemampuan diri) mempunyai nilai positif yaitu 0.269 , hal ini menunjukkan bahwa variabel kemampuan diri mempunyai pengaruh positif terhadap kinerja pegawai di Dinas Kependudukan Dan Pencatatan Sipil Kabupaten Aceh Barat.

3) Nilai koefisien regresi $X_{2}$ (komitmen organisasi) mempunyai nilai positif yaitu 0.383 , hal ini menunjukkan bahwa variabel komitmen organisasi mempunyai pengaruh positif terhadap kinerja pegawai di Dinas Kependudukan Dan Pencatatan Sipil Kabupaten Aceh Barat.

4) Nilai koefisien regresi $X_{3}$ (budaya organisasi) mempunyai nilai positif yaitu 0.337, hal ini menunjukkan bahwa variabel budaya organisasi mempunyai pengaruh positif terhadap kinerja pegawai di Dinas Kependudukan Dan Pencatatan Sipil Kabupaten Aceh Barat.

\subsection{Pengaruh Kemampuan Diri Terhadap Kinerja Pegawai Di Dinas Kependudukan Dan Pencatatan Sipil Kabupaten Aceh Barat.}

Untuk mengetahui pengaruh kemampuan diri terhadap kinerja pegawai di Dinas Kependudukan Dan Pencatatan Sipil Kabupaten Aceh Barat digunakan uji-t, sedangkan untuk melihat besarnya pengaruh digunakan nilai Beta atau Standardized Coefficient Beta.

Tabel. 5. Pengaruh kemampuan diri terhadap kinerja

\begin{tabular}{|l|r|r|r|r|r|}
\hline \multirow{2}{*}{ Model } & \multicolumn{2}{|c|}{$\begin{array}{c}\text { Unstandardized } \\
\text { Coefficients }\end{array}$} & $\begin{array}{c}\text { Standardized } \\
\text { Coefficients } \\
\text { Beta }\end{array}$ & \multirow{2}{*}{$\mathrm{t}$} & \multirow{2}{*}{ Sig. } \\
\cline { 2 - 3 } & \multicolumn{1}{|c|}{$\mathrm{B}$} & \multicolumn{1}{|c|}{ Std. Error } & & \\
\hline (Constant) & .989 & 8.085 & & .122 & .904 \\
\hline Kemampuan diri & .269 & .129 & .298 & 2.092 & .046 \\
\hline
\end{tabular}

a. Dependent Variable : Kinerja

Dari Tabel 5 diatas diperoleh nilai $\mathrm{t}_{\text {hitung }}$ sebesar 2.092. Penelitian ini menggunakan taraf signifikansi $(\alpha: 0.05)$ dan Derajat Kebebasan (DK) dengan ketentuan DK $=\mathrm{n}-2$, atau $32-2$ $=30$. Dengan ketentuan tersebut, diperoleh nilai $t_{\text {tabel }}$ sebesar 2.042. Dengan kriteria hipotesis sebagai berikut :

Jika nilai $t_{\text {hitung }}>t_{\text {tabel }}$, maka hipotesis penelitian diterima.

Jika nilai $\mathrm{t}_{\text {hitung }}<\mathrm{t}_{\text {tabel }}$, maka hipotesis penelitian ditolak.

Dari hasil pengolahan data diperoleh nilai $t_{\text {hitung }}>t_{\text {tabel }}(2.092>2.042)$ dan nilai signifikasi lebih kecil dari nilai $\alpha: 0.05$ yaitu $0.046<0.05$, sehingga hipotesis yang diajukan dalam penelitian ini diterima. Artinya variabel kemampuan diri secara partial berpengaruh positif dan signifikan terhadap kinerja pegawai di Dinas Kependudukan Dan Pencatatan Sipil Kabupaten Aceh Barat. Besarnya pengaruh variabel kemampuan diri terhadap kinerja pegawai di Dinas Kependudukan Dan Pencatatan Sipil Kabupaten Aceh Barat sebesar 0.298 atau $29.80 \%$. Hasil penelitian ini sejalan dengan hasil penelitian Abdulkarim Jailan (2016); Jajang Amiroso, Mulyanto (2015);
Makawi, Umar, Normajatun dan Abdul Haliq. (2015); dan Suyanto (2018), yang mana kesemuanya menyatakan kemampuan diri berpengaruh positif dan signifikan terhadap kinerja. Pada umumnya kapasitas individu atau kemampuan individu seseorang dipengaruhi oleh kontribusi pengetahuan (knowledge), ketrampilan (skills), dan sikap (attitude) yang tertanam didalam pikiran yang berasal dari dalam diri sendiri, sehingga jika kemampuan yang dimiliki pegawai sudah baik maka kinerjanya akan meningkat, begitu juga sebaliknya jika kemampuan pegawai belum baik maka hasil kerja juga akan menurun atau kurang baik.

\subsection{Pengaruh Komitmen Organisasi Terhadap Kinerja Pegawai Di Dinas Kependudukan Dan Pencatatan Sipil Kabupaten Aceh Barat.}

Untuk mengetahui pengaruh komitmen organisasi terhadap kinerja pegawai di Dinas Kependudukan Dan Pencatatan Sipil Kabupaten Aceh Barat digunakan uji-t, sedangkan untuk melihat besarnya pengaruh digunakan nilai Beta atau Standardized Coefficient Beta. 
Tabel 6. Pengaruh komitmen organisasi terhadap kinerja

\begin{tabular}{|l|r|r|r|r|r|}
\hline \multirow{2}{*}{ Model } & \multicolumn{2}{|c|}{$\begin{array}{c}\text { Unstandardized } \\
\text { Coefficients }\end{array}$} & $\begin{array}{c}\text { Standardized } \\
\text { Coefficients } \\
\text { Beta }\end{array}$ & \multirow{2}{*}{$\mathrm{t}$} & \multirow{2}{*}{ Sig. } \\
\cline { 2 - 3 } & \multicolumn{1}{|c|}{ B } & Std. Error & & \\
\hline (Constant) & .989 & 8.085 & & .122 & .904 \\
\hline Komitmen organisasi & .383 & .145 & .374 & 2.632 & .014 \\
\hline
\end{tabular}

a. Dependent Variable : Kinerja

Dari Tabel 6 diatas diperoleh nilai $\mathrm{t}_{\text {hitung }}$ sebesar 2.632. Penelitian ini menggunakan taraf signifikansi $(\alpha: 0.05)$ dan Derajat Kebebasan (DK) dengan ketentuan DK $=\mathrm{n}-2$, atau $32-2$ $=30$. Dengan ketentuan tersebut, diperoleh nilai $\mathrm{t}_{\text {tabel }}$ sebesar 2.042. Dengan kriteria hipotesis sebagai berikut :

Jika nilai $t_{\text {hitung }}>t_{\text {tabel }}$, maka hipotesis penelitian diterima.

Jika nilai $t_{\text {hitung }}<t_{\text {tabel }}$, maka hipotesis penelitian ditolak.

Dari hasil pengolahan data diperoleh nilai $t_{\text {hitung }}>t_{\text {tabel }}(2.632>2.042)$ dan nilai signifikasi lebih kecil dari nilai $\alpha: 0.05$ yaitu $0.014<0.05$, sehingga hipotesis yang diajukan dalam penelitian ini diterima. Artinya variabel komitmen organisasi secara partial berpengaruh positif dan signifikan terhadap kinerja pegawai di Dinas Kependudukan Dan Pencatatan Sipil Kabupaten Aceh Barat. Besarnya pengaruh variabel komitmen organisasi terhadap kinerja pegawai di Dinas Kependudukan Dan Pencatatan Sipil Kabupaten Aceh Barat sebesar 0.374 atau $37.40 \%$. Hasil penelitian ini sejalan dengan hasil penelitian dari Windy dan Gusnati (2012); Murgianto, Sulasmi, S., dan Suhermin. (2016); Sety+aningdyah (2013); Soepardjo, Tanisa Arsya dan Nugrohoseno, Dwiarko (2014), kesemuanya menyatakan komitmen organisasi berpengaruh positif dan signifikan terhadap kinerja. Jika pegawai mempunyai komitmen yang baik terhadap organisasi, maka akan berdampak pada peningkatan kinerja pegawai, begitu juga sebaliknya jika komitmen pegawai terhadap organisasi kurang baik maka berdampak pada penurunan kinerjanya.

\subsection{Pengaruh Budaya Organisasi Terhadap Kinerja Pegawai Di Dinas Kependudukan Dan Pencatatan Sipil Kabupaten Aceh Barat. \\ Untuk mengetahui pengaruh budaya} organisasi terhadap kinerja pegawai di Dinas Kependudukan Dan Pencatatan Sipil Kabupaten Aceh Barat digunakan uji-t, sedangkan untuk melihat besarnya pengaruh digunakan nilai Beta atau Standardized Coefficient Beta.

Tabel 7. Pengaruh budaya organisasi terhadap kinerja

\begin{tabular}{|c|c|c|c|c|c|}
\hline \multirow[t]{2}{*}{ Model } & \multicolumn{2}{|c|}{$\begin{array}{c}\text { Unstandardized } \\
\text { Coefficients }\end{array}$} & \multirow{2}{*}{$\begin{array}{c}\text { Standardized } \\
\text { Coefficients } \\
\text { Beta }\end{array}$} & \multirow[t]{2}{*}{$\mathrm{t}$} & \multirow[t]{2}{*}{ Sig. } \\
\hline & B & Std. Error & & & \\
\hline (Constant) & .989 & 8.085 & & .122 & .904 \\
\hline Budaya organisasi & .337 & .139 & .336 & 2.433 & .022 \\
\hline
\end{tabular}

a. Dependent Variable : Kinerja

Dari Tabel 7 diatas diperoleh nilai $t_{\text {hitung }}$ sebesar 2.433. Penelitian ini menggunakan taraf signifikansi $(\alpha: 0.05)$ dan Derajat Kebebasan (DK) dengan ketentuan DK $=\mathrm{n}-2$, atau $32-2$ $=30$. Dengan ketentuan tersebut, diperoleh nilai $\mathrm{t}_{\text {tabel }}$ sebesar 2.042. Dengan kriteria hipotesis sebagai berikut :

Jika nilai $t_{\text {hitung }}>t_{\text {tabel }}$, maka hipotesis penelitian diterima.

Jika nilai $t_{\text {hitung }}<t_{\text {tabel }}$, maka hipotesis penelitian ditolak.

Dari hasil pengolahan data diperoleh nilai $t_{\text {hitung }}>t_{\text {tabel }}(2.433>2.042)$ dan nilai signifikasi lebih kecil dari nilai $\alpha: 0.05$ yaitu $0.022<0.05$, sehingga hipotesis yang diajukan dalam penelitian ini diterima. Artinya variabel budaya organisasi secara partial berpengaruh positif dan signifikan terhadap kinerja pegawai di Dinas Kependudukan Dan Pencatatan Sipil Kabupaten Aceh Barat. Besarnya pengaruh variabel budaya organisasi terhadap kinerja pegawai di Dinas Kependudukan Dan Pencatatan Sipil Kabupaten Aceh Barat sebesar 0.336 atau $33.60 \%$. Hasil penelitian ini sejalan dengan hasil penelitian dari Jatilaksono, Raditya (2016); Maskur, (2010); Muchtar Adama (2014); Pranoto, Paulus Sugiyo. (2014); Soepardjo, Tanisa Arsya dan Nugrohoseno, Dwiarko (2014), kesemuanya menyatakan bahwa budaya organisasi berpengaruh positif 
dan signifikan terhadap kinerja. Budaya organisasi bermanfaat bagi pegawai (misalnya, memperhatikan dan berorientasi pada prestasi, keadilan dan sportivitas), maka dapat diharapkan adanya peningkatan kinerja yang lebih baik dari pada sebelumnya. Sebaliknya jika budaya organisasi yang ada bertentangan dengan tujuan, kebutuhan dan motivasi pribadi, kemungkinan yang timbul adalah kinerja pegawai menjadi menurun
3.5. Pengaruh Kemampuan Diri, Komitmen Organisasi dan Budaya Organisasi Terhadap Kinerja Di Dinas Kependudukan Dan Pencatatan Sipil Kabupaten Aceh Barat

Untuk mengetahui pengaruh kemampuan diri, komitmen organisasi dan budaya organisasi terhadap kinerja pegawai di Dinas Kependudukan Dan Pencatatan Sipil Kabupaten Aceh Barat digunakan uji-F.

Tabel 8. Pengaruh kemampuan diri, komitmen organisasi dan budaya organisasi terhadap kinerja

\begin{tabular}{|l|l|r|r|r|r|c|}
\hline \multirow{2}{*}{ Model } & & $\begin{array}{c}\text { Sum of } \\
\text { Squares }\end{array}$ & \multicolumn{1}{c|}{ df } & $\begin{array}{c}\text { Mean } \\
\text { Square }\end{array}$ & \multicolumn{1}{c|}{ F } & \multicolumn{1}{c|}{ Sig. } \\
\hline \multirow{4}{*}{1} & Regression & 173.323 & 3 & 57.774 & 9.182 & $.000^{\mathrm{a}}$ \\
\cline { 2 - 7 } & Residual & 176.177 & 28 & 6.292 & & \\
\cline { 2 - 7 } & Total & 349.500 & 31 & & & \\
\hline
\end{tabular}

Dependent Variable : Kinerja

Dari Tabel 8 di atas diperoleh nilai $\mathrm{F}_{\text {hitung }}$ sebesar 9.182. Penelitian ini menggunakan taraf signifikansi $(\alpha: 0.05)$ dan Derajat Kebebasan (DK) dengan ketentuan numerator : jumlah variabel -1 atau $4-1=3$, dan jumlah sampel dikurang 4 atau $32-4=28$. Dengan ketentuan tersebut, diperoleh nilai $\mathrm{F}_{\text {tabel }}$ sebesar 2.90 . Dengan kriteria pengujian hipotesis sebagai berikut :

Jika $\mathrm{F}_{\text {hitung }}>\mathrm{F}_{\text {tabel, }}$, maka hipotesis penelitian diterima.

Jika $F_{\text {hitung }}<\mathrm{F}_{\text {tabel}}$, maka hipotesis penelitian ditolak.

Dari hasil perhitungan diperoleh nilai $F_{\text {hitung }}>F_{\text {tabel }}(9.182>2.90)$ dan nilai signifikasi $0.00<0.05$, sehingga hipotesis yang diajukan dalam penelitian ini diterima. Artinya variabel kemampuan diri, komitmen organisasi dan budaya organisasi secara simultan berpengaruh positif dan signifikan terhadap kinerja pegawai di Dinas Kependudukan Dan Pencatatan Sipil Kabupaten Aceh Barat. Dengan demikian model regresi ini sudah layak dan benar dan dapat disimpulkan bahwa variabel kemampuan diri, komitmen organisasi dan budaya organisasi berpengaruh terhadap kinerja pegawai di Dinas Kependudukan Dan Pencatatan Sipil Kabupaten Aceh Barat.

\subsection{Uji Determinan}

Uji determinan adalah untuk mengetahui seberapa besar pengaruh variabel kemampuan diri, komitmen organisasi dan budaya organisasi terhadap kinerja pegawai di Dinas Kependudukan Dan Pencatatan Sipil Kabupaten Aceh Barat, dan dapat dilihat dari model summary, khususnya nilai Adjusted Rsquare.

Tabel 9. Model summary ${ }^{\mathrm{b}}$ pengaruh kemampuan diri, komitmen organisasi dan budaya organisasi

\begin{tabular}{|l|l|r|r|r|}
\hline \multicolumn{5}{|c|}{ terhadap kinerja } \\
Model & $R$ & $R$ Square & $\begin{array}{c}\text { Adjusted } R \\
\text { Square }\end{array}$ & $\begin{array}{c}\text { Std. Error of the } \\
\text { Estimate }\end{array}$ \\
\hline 1 & $.704^{\mathrm{a}}$ & .496 & .442 & 2.50839 \\
\hline
\end{tabular}

Dependent Variable : Kinerja

Besarnya Tabel 9 diatas diperoleh nilai Adjusted Rsquare $\left(\mathrm{r}^{2}\right)$ sebesar 0.442. Nilai tersebut mempunyai maksud bahwa pengaruh variabel kemampuan diri, komitmen organisasi dan budaya organisasi terhadap kinerja pegawai di Dinas Kependudukan Dan Pencatatan Sipil Kabupaten Aceh Barat sebesar 44.20\%, sedangkan sisanya sebesar $55.80 \%$ dipengaruhi oleh faktor-faktor lain yang tidak diteliti. Dengan kata lain variabel kinerja pegawai di
Dinas Kependudukan Dan Pencatatan Sipil Kabupaten Aceh Barat dapat diterangkan oleh variabel kemampuan diri, komitmen organisasi dan budaya organisasi sebesar 44.20\%, sedangkan sisanya sebesar $55.80 \%$ disebabkan oleh variabel-variabel lain yang tidak diteliti. 


\section{Kesimpulan}

Berdasarkan pada pembahasan pada bab sebelumnya, maka dapat ditarik kesimpulan dari penelitian ini sebagai berikut :

1) Variabel kemampuan diri secara partial berpengaruh positif dan signifikan terhadap kinerja pegawai di Dinas Kependudukan Dan Pencatatan Sipil Kabupaten Aceh Barat.

2) Variabel komitmen organisasi secara partial berpengaruh positif dan signifikan terhadap kinerja pegawai di Dinas Kependudukan Dan Pencatatan Sipil Kabupaten Aceh Barat.

3) Variabel budaya organisasi secara partial berpengaruh positif dan signifikan terhadap kinerja pegawai di Dinas Kependudukan Dan Pencatatan Sipil Kabupaten Aceh Barat.

4) Variabel kemampuan diri, komitmen organisasi dan budaya organisasi secara simultan berpengaruh positif dan signifikan terhadap kinerja pegawai di Dinas Kependudukan Dan Pencatatan Sipil Kabupaten Aceh Barat.

\section{DAFTAR PUSTAKA}

Abdulkarim Jailan, (2016), Pengaruh Kemampuan Kerja, Motivasi Kerja dan Fasilitas Kerja terhadap Kinerja Pegawai Kantor Pertanahan Kota Palangka Raya . JSM (Jurnal Sains Manajemen) Program Magister Sains Manajemen UNPAR, ISSN: 2302-1411, Volume V, Nomor 2, September 2016, pp: 142-154.

Abdullah, Z., Darwanis., dan Zein, B. (2013). Pengaruh sikap kerja terhadap kinerja auditor melalui motivasi kerja sebagai variabel intervening. Jurnal Akuntansi, Volume 2, No. 1, November 2012

Barnardin (2008), Mengelola Sumber Daya Manusia, PT. Gramedia, Jakarta

Cascio (2016), Organisasi. Edisi Kedelapan, Jilid 2. Binarupa Aksara . Jakarta

Colquitt, LePine, Wesson, 2014, Organizational Behavior Improving Performance and Commitment in The Workplace, Mc Graw Hill International Edition

Cross, T.M dan Lynch. R.R. (2012). Peniliaian dan Evaluasi Kinerja: Konsep dan Praktik. Jakarta. Penerbit Ghalia Indonesia

Dessler, Gary. (2013). Manajemen Sumber Daya Manusia (Jilid I). Jakarta : Indeks

Gibson, James L., Ivancevich, John M., Donnely, James H., and Konopaske (2014) Organizations: Behavior, Structure, Processes,New York, McGraw Hill.
Gorda, IGN. 2012. Manajemen Sumber Daya Manusia. Edisi Revisi. Cetakan Kedua. Denpasar: Astabrata

Handoko T, Hani (2008), Manajemen Personalia dan Sumber Daya Manusia, Edisi Kedua , BPFE Yogyakarta

Hasibuan, Malayu S. P. (2008). Manajemen Sumber Daya Manusia. Edisi Revisi Jakarta: PT. Bumi Aksara

Husnan (2012), Manajemen Personalia dan Sumber Daya Manusia, Edisi Kedua, BPFE Yogyakarta

Ivancevich, G., and Koropaske, D., (2010) Organizations: Behavior, Stucture, Process, Singapore, McGraw Hill Company

Ivancevich, John M., Konopaske, Robert., and Matteson, Michael T., (2013) Organizational Behavior and Management, $7^{\text {th }}$ edition, McGraw Hill, Alih Bahasa Gina Gania, Perilaku dan Manajemen Organisasi, Jilid 1, Edisi 7, Jakarta, Erlangga

Jajang Amiroso, Mulyanto (2015), Influence of Discipline, Working Environment, Culture of Organization and Competence on Workers' Performance through Motivation, Job Satisfaction (Study in Regional Development Planning Board of Sukoharjo Regency), EJBM Reading Tools, Vol. 7 No. 36 (2015).

Makawi, Umar, Normajatun dan Abdul Haliq. (2015). Analisis Pengaruh Kompetensi Terhadap Kinerja Pegawai Dinas Perindustrian Dan Perdagangan Kota Banjarmasin. Al - Ulum Ilmu Sosial dan Humaniora, Volume 1 Nomor 1, pp: 17-26

Liao (2012), The impact of work values, work attitudes on job performance of Green Energy Industry Employee in Taiwan

Mangkunegara, Anwar, Prabu. (2014). Evaluasi Kinerja SDM, Cetakan 4, Bandung : Refika Aditama

Martoyo, Susili (2012), Manajemen Sumber Daya Manusia, Edisi Ketiga, Cetakan Keempat, Ghalia Jakarta

Mathis, Robert L and Jackson, John H, 2006, Manajemen Sumber Daya Manusia, Edisi 10, terjemahan, Salemba Empat

Milkovich, T George and Newman, Jerry M, 2008,Competency, Mc Graw Hill International Edition

Moekijat (2008), Latihan dan Pengembangan Sumber Daya Manusia, Cetakan ke Empat, Maju Mundur, Bandung

Murphy, Kevin R and Cleveland, Jeanette N, 2012, Performance Appraisal : An 
Organizational Perspective,Colorado State University

Nitisemito S Alex (2008), Manajemen Personalia, Cetakan Keempat, Ghalia, Jakarta

Petty, Ricard E., Brinol, Pablo., dan Tormala, Zakary L., (2012) 'Thought Confidence as a Determinant of Persuasion: The Self ValidationHypothesis", Journal of Personality and Social Psychology, pp. 722734

Riduwan. (2013). Skala Pengukuran VariabelVariabel Bandung : Alfabeta

Rivai, Veithzal dan Sagala, Ella Jauvani. (2014). Manajemen Sumber Daya Manusia Untuk Perusahaan : Dari Teori ke Praktek. Jakarta : PT. Rajagrafindo Persada

Robbins, Stephen P., dan Judge, Timothy A., (2008) Perilaku Organisasi, Terjemahan Edisi Dua Belas, Jakarta, Salemba Empat. (2011) Organizational Behavior, $13^{\text {th }}$ edition, New Jersey, Pearson Education, Upper Saddle River

Sedarmayanti. (2012). Good Governance (Kepemerintahan Yang Baik), Bandung : Mandar Maju

Siagian, Sondang. (2008). Manajemen Sumber Daya Manusia (cetakan 15). Jakarta: Bumi Aksara

Sink, R dan Tuttle, J.K. (2014). Evaluasi Kinerja. Jakarta: Indeks Kelompok Gramedia

Sri Yani 2005, Hubungan Antara Kompetensi Manaajerial dan Komitmen Organisasi Dengan Kinerja Pejabat Struktural Eselon III-IV Pada Sekretariat Jenderal Dewan Perwakilan Rakyat Republik Indonesia, Tesis, Universitas Indonesia, Jakarta

Sugiyono. 2010. Metode Penelitian Bisnis. Alfabeta Bandung

Terry George \& Rue, Leslie W alih bahasa Terry (2008), Dasar-Dasar Manajemen, Cetakan Ketujuh Bumi Aksara Jakarta

Torang Sitanggang 2005, Pengaruh Persepsi Mengenai Komitmen dan Budaya Organisasi Terhadap Persepsi Mengenai Kinerja Pegawai Pajak Di Direktorat Pemerikasaan, Penyidikan dan Penagihan Pajak Direktorat Jenderal Pajak, Tesis, Universitas Indonesia

Triton PB (2005), Paradigma Baru Manajemen Sumber Daya Manusia, Tugu Yogyakarta. (2006), SPSS 12.00 Terapan Riset

Statistik Parametrik, Andi Yogyakarta.
Ulida L. Toruan 2012, Hubungan Antara Kompetensi dan Motivasi Terhadap Kinerja Pejabat Struktural di Badan Kepegawaian Negara, Tesis, Universitas Indonesia, Jakarta Wibowo, (2011), Manajemen Kinerja. Cetakan Pertama. Jakarta: Raja Grafindo Persada

Zauhar. (2008). Motivasi dan Pemotivasian dalam Manajemen. Raja Grafindo Persada, Jakarta

Zin, R. M., (2012) "Perception of Professional Engineers Toward Quality of Work Life and Organizational Commitment a Case Study", Gadjah Mada InternationalJournal of Business, 6(3), 323-334 